\title{
Strengthening Risk Control and Compliance Management
}

As the company goes global, Huawei faces many risks both externally and internally. External risks involve geopolitics, financial crises, unstable economic growth, shrinking investment, fluctuating exchange rates, strict controls over foreign exchange, anti-globalization, protectionism, antidumping, labor disputes, changes in customer business models, and other challenges. Internal risks include risks associated with blind expansion, product quality, business continuity, supply, long overdue inventory, long overdue accounts receivable, cyber security, user privacy protection, taxation, trade compliance, legal compliance, and corruption. All of these risks pose tremendous challenges to Huawei's growth in the global market. When the world is in an imbalanced state, will Huawei keep its balance? How will it do so?

In a complex and nonlinear world, there is no guaranteed correlation between the strength of a cause and its result. Likewise, the potential impact of a local problem is not determined by how big the problem is. As Huawei grows in scale, network coverage increases, and network architecture becomes increasingly complicated, a butterfly effect has been observed. This means that changes in one area can spread and cause severe losses across the whole company, and a small problem can evolve into a larger one and explode.

Despite this, risks are accompanied by opportunities. Huawei does not stop progressing because of risks, nor does it ignore risks as it moves ahead. Huawei's approach to future risks is to use the certainty of rules to

(C) The Author(s) 2019

W. Huang, Built on Value, https://doi.org/10.1007/978-981-13-7507-1_5 
deal with the uncertainty of results and use the certainty of legal compliance to deal with the uncertainty of international politics. The company must strictly monitor internal and external compliance, and strictly operate within the boundaries of its business. It must identify and control risks while harvesting more crops, because the latter is the purpose of the former. The company must keep improving its risk control system to ensure that it operates in compliance with rules and gain freedom in the course of development.

This chapter discusses the rules for managing the internal and external risks that Huawei faces. Detailed rules on oversight, internal controls, and internal audit will be explained in the corresponding chapters in Part II of the book.

\subsection{Controlling Risks During Expansion: The Purpose of Control Is to Ensure Sustainable and Profitable Growth}

\subsubsection{Can Huawei Keep Its Balance in an Unbalanced World? How Can It Do So?}

As our company grows in scale and our business becomes increasingly complicated, we also face more internal and external risks. (Ren Zhengfei: Wearing American Shoes and Starting from Scratch to Build Huawei's Internal Control System-An Introduction to IBM's Internal Control Practices and EMT's Guidelines for Building Huawei's Internal Control System, Huawei Executive Office Speech No. [2007] 032)

Over the next five to ten years, the world will become increasingly complicated. When the world is imbalanced, can we keep our balance? How can we do so? In such a complex external environment, we also face significant pressure from risks such as shrinking investment, great fluctuations in exchange rates, protectionism, rising wages, labor disputes, and large-scale demonstrations. These are all serious challenges that we face in this era. (Ren Zhengfei: Speech at the Meeting of the New Board of Directors and the New Supervisory Board, Huawei Executive Office Speech No. [2011] 001)

Externally, the global financial environment is still turbulent and there are no signs of recovery from the European sovereign debt crisis, making consumers less willing to buy, governments reluctant to invest in 
infrastructure, and carriers more cautious about capital expenditure (CAPEX). Exchange rates are fluctuating wildly, exposing Huawei to a greater risk of exchange losses. In addition, inflation in emerging markets has not been effectively controlled, driving up operating costs and squeezing the company's profitability. Political turmoil in some countries and regions has affected the continuity and security of Huawei's business operations. There are also significant operating risks caused by geopolitical issues. Trade barriers caused by political maneuvering between large nations, protectionism, cyber security issues, and other factors make our business environment more challenging as well. Weak global demand, the bursting of asset bubbles, and financial deleveraging are likely to occur simultaneously, thus increasing uncertainty in the global economy. (Ren Zhengfei: Guidelines on the Analysis of the Business Environment and Key Business Strategies, Corp. Doc. No. [2012] 081)

More than a decade ago, former Nortel CEO William Owens suggested that we work together to develop low-orbit satellites, similar to the solutions that Facebook and Google actually deploy today. We didn't do that, because satellites might have involved military projects. We committed ourselves to never developing equipment for military purposes, or touching the confidential information of others. As a private company, we honor this commitment. So, is it possible that something will emerge to reshape today's telecom networks? I believe so. Motorola's Iridium satellite initiative was indeed very good, but unfortunately, fiber optics appeared, and turned the initiative upside down. Who's to say that telecom networks will not be reshaped? (Ren Zhengfei: Remarks at Meetings with Huawei Fellows, Huawei Executive Office Speech No. [2016] 069)

\subsubsection{Do Not Focus Exclusively on Opportunities Without Considering Risks}

We must ensure trade compliance and pay attention to anti-dumping. In some places we set our prices very low in an effort to compete. We must stop doing this in some contracts because we will suffer huge losses if antidumping measures are taken against us. (Ren Zhengfei: Implementing Oversight with Care, Huawei Executive Office Speech No. [2011] 013)

In terms of investment strategy, although we have numerous opportunities in the industry, we should not focus exclusively on opportunities without considering risks. We should guard against having ambitious strategic pursuits but lacking the commercial operations capabilities to convert 
them into financial results. Currently, most business departments follow a $\mathrm{V}$-shaped path when formulating business and strategic plans, claiming that they have not reached the break-even point. They all hope for a better tomorrow in spite of the difficulties today. They all ask for more resources from $H Q$, but stick to an unrealistic vision with respect to future business results. We need to consider what to invest in, what to give up, and what investment pace to adopt. We also need to decide whether to invest before making profit, or whether to invest while making profit and then increase investment. (Ren Zhengfei: Guidelines on the Analysis of the Business Environment and Key Business Strategies, Corp. Doc. No. [2012] 081)

The Consumer BG must remain profit-centric and strictly control inventory risks. Survival is the first step to the future. We must change our value assessment system from one that is technology-oriented to one that is oriented towards business success. The Consumer BG has become part of Huawei's core business and a core business must create value. Value here does not just mean leading technology. (Ren Zhengfei: Avoiding Opportunism in the Era of Big Opportunities-Speech at the Luncheon with the Administrative Team of the Consumer BG, Huawei Executive Office Speech No. [2014] 025)

The Consumer BG must enhance strategic partnerships with suppliers. If we keep forcing down their prices, we will face risks. A problem with a single component could cause a whole batch of phones to malfunction. If the batch is very large, the Consumer BG might face a disaster. So first, we need to control inventory, and second, we need to improve our relationships with suppliers. We must use high-quality components to make highquality phones. (Ren Zhengfei: Speech at the EMT ST Meeting on August 28, 2015, Huawei Executive Office Speech No. [2015] 132)

As the capacity and transmission speed of our products increase, we will face greater risks. Any small problem can evolve into a big one and explode. To make our products more reliable, we have to depend on the meticulous German and Japanese people, and on designers in China to improve quality. (Ren Zhengfei: Minutes of a Meeting with Employees of the Japan Representative Office and the Japan Research Center, Huawei Executive Office Speech No. [2016] 080)

The year 2016 has seen a flock of black swans - both political and economic - sweep across the globe. Nevertheless, we have remained focused on our strategy and have patiently applied ourselves to making breakthroughs and creating real value for our customers. The macro environment is full of risks: the ongoing transformation of the ICT industry, mounting business pressures faced by our customers, and escalating 
economic uncertainty around the globe. As we aim to seize new opportunities, we must be better prepared for risks. (Xu Zhijun: Focusing on Creating Value for Customers, Achieving Sustainable Growth, Huawei Executive Office Speech No. [2016] 099)

\subsubsection{Pursuing Sustainable and Profitable Growth and Curbing Blind Expansion}

Over the past two decades, Huawei has been an opportunity-driven company. This has enabled us to become what we are today. In the next two decades, Huawei should be a profit-driven company. We should not seek to become a company with the largest scale; instead, we should pursue more profits and stable growth. (Source: Positioning and Responsibilities of the Finance Committee Under the Board of Directors [Provisional], Board of Directors Doc. No. [2012] 002)

The SDC and the Human Resources Committee (HRC) must work hard to drive growth, but they are constrained by the Finance Committee (FC). What sort of constraints are they subject to? First, they can only spend money within their budgets; second, they must ensure that profit targets are hit. (Source: Positioning and Responsibilities of the Finance Committee Under the Board of Directors [Provisional], Board of Directors Doc. No. [2012] 002)

Opportunities do not necessarily emerge from new industries. We must have controls and constraints in place for entry into new industries. There are also opportunities in our strategic businesses. The FC decides on the resources allocated to different opportunities and set different profit targets for them. (Ren Zhengfei: Using Budgeting and Accounting to Drive Sustainable and Profitable Growth in Huawei's Core BusinessSpeech at the Retreat on the Positioning and Responsibilities of the Finance Committee, 2012)

Pursuing a diversified business portfolio presents a big challenge to us. We need to determine our direction, pace, and priority, to ensure that we are growing stably with risks under control. (Guo Pingl: Effectively Managing Corporate Value to Pursue Sustainable and Profitable Growth, Huawei Executive Office Speech No. [2012] 005)

Every business unit needs to set higher profit targets, and curb their desire to expand blindly. The company asks each business unit to turn in a profit. Strategically, this is to prevent blind expansion of new business and

\footnotetext{
${ }^{1}$ Guo Ping was the Rotating CEO of Huawei at the time.
} 
to crack down on irrational expansion. If a new business turns out to be worth expansion and is part of our core business, we can give it space to grow. Otherwise, the business needs to turn in more profits if it wants to grow. We have a plan in place that helps to prevent blind expansion by asking for higher profits from new projects. If every business unit focuses on scaling out and becomes bloated like they used to, but contribute no profit to the company, then our company will be ultimately dragged down. (Guo Ping: Effectively Managing Corporate Value to Pursue Sustainable and Profitable Growth, Huawei Executive Office Speech No. [2012] 005)

The economic prospects don't look good. We don't allow blind development. When talking about market space, we must be realistic and emphasize the contributions being made right now. We are in a period of big risks. We must be clear about our strategy and make full use of our strengths, as this is necessary to generate enough profits to ensure our survival. Departments that do not generate profits must be downsized. If a product doesn't generate any profits, then don't develop it blindly. Don't say that it will make contributions in the future. If we cannot survive, then future contributions are meaningless. No one should build their success on the backs of others. Don't be overly optimistic when making estimations; be more conservative. (Ren Zhengfei: Speech at a Work Report of the Network Energy Product Line, Huawei Executive Office Speech No. [2012] 043)

We should take a pragmatic approach to countries that we predict we won't have big opportunities when looking at their future economic growth. If we don't have big opportunities in a war-torn country, we should not maintain large teams there. In the future, we need to downsize local offices in countries where we don't see large growth potential. We only need to engage in sales activities, with a focus on services. For these countries, we only look at their profits, not sales revenue. (Ren Zhengfei: Minutes of the Report on the Opportunity to Order for 2017, EMT Meeting Minutes No. [2016] 021)

\subsubsection{Balancing Expansion and Control}

We have a team of more than 80,000 employees. Such a large team losing momentum would be disastrous. So we must continue to forge ahead. No team can afford to fail, as this could cause a chain reaction. We must remain prepared to fight hard battles and make improvements during this process. We cannot afford to stop to make improvements. We have already assigned a larger weight to positive cash flow and positive profit margins 
during performance appraisals. This acts as a tight band around the head of our staff on the front line, and we should not place any more shackles on them. Otherwise, the whole company will have to stop to make improvements. This is too risky. In performance appraisals, we have shifted our focus to profitable and self-sustaining growth. This change has already begun and will not progress too quickly. As long as we move in the right direction, we will achieve the desired results. (Ren Zhengfei: Speech at a Meeting with the IFS Project Team and Staff from Finance, Huawei Executive Office Speech No. [2009] 004)

We must strike a balance between expansion and control and strengthen our strategic focus. We must be selective about what we do and what we don't. Only in this way can we seize the strategic high ground. We must continue to focus on our core business. Then in three to five years, we can find a way out. (Ren Zhengfei: Guidelines on the Key Points of Huawei's 2012 Business Management)

We must improve operations quality and drive sustainable and profitable growth. As we increase investment, we must better incorporate the company's strategic pursuits into business goal setting and closed-loop performance appraisals. We need to improve the way we manage risks, maintain robust, standardized operations, and use the certainty of rules to deal with the uncertainty of the global economy. (Ren Zhengfei: Guidelines on the Key Points of Huawei's 2012 Business Management)

A global business presence will lay a foundation for our survival in the global market. We must increase investment and build a corporate culture that allows effective deployment of talent, capabilities, experience, and resources around the world. This will enable us to forge extensive partnerships with our stakeholders in countries and regions where we operate, helping create a harmonious ecosystem and avoid possible strategic risks in the future. (Ren Zhengfei: Guidelines on the Key Points of Huawei's 2012 Business Management)

\subsection{A Multi-faceted System for Controlling Financial Risks at Huawei}

\subsubsection{The "Four Threes" System for Risk Control}

From a financial perspective, we have established a system of "Four Threes" to manage the company's risks. The "Four Threes" are the three categories of risks, which are strategic risks, operational risks, and financial risks; the three lines of defense built into every business activity; the three 
blue teams established in London, New York, and Tokyo that operate independently to challenge red teams; and the three layers of review established by three independent organizations, which are CFOs, Accounting, and Treasury. (Meng Wanzhou: Outline of the Report on the Operations of the Financial Risk Control Center in London, 2017)

Three Categories of Risks We have defined risks by category. For example, in the strategic risk category, we know that our company will surely face technical risks: Will a disruptive technology emerge to challenge our technological model? For operational risks, we can look at supply. The recent problem with the flash memory of our P10 series smartphones is a typical supply risk. The upstream supplier controlled the number of parts supplied to Huawei. The third risk category is financial risks, which include foreign exchange risks and tax risks. We assign a single individual to be responsible for each category of risks, and they manage risks throughout the company by dismantling department silos and dissolving organizational boundaries. This individual identifies, assesses, responds to, monitors, and reports risks to minimize their impact. This is how we manage the three categories of risks. (Meng Wanzhou: Outline of the Report on the Operations of the Financial Risk Control Center in London, 2017)

Three Lines of Defense In all circumstances, the first line of defense is business managers. They naturally assume process responsibilities and incorporate risk management and control activities into their everyday work. The second line of defense is the internal control and inspection teams that provide support to business managers. The internal control team develops an internal control methodology, similar to a physical examination checklist, to help business managers perform self-checks. With this checklist, business managers can review and identify areas for improvement. The inspection team identifies major risks and most likely problems in processes and focuses on major conflicts and major risks. These two teams are assistants to business managers, reporting to business managers and helping them control $90 \%$ of operational risks. The third line of defense is the audit team. They report independently to top management. This team conducts random checks on specific activities to establish deterrence across the whole organization. This is how we build three lines of defense into every business activity. (Meng Wanzhou: Outline of the Report on the Operations of the Financial Risk Control Center in London, 2017) 
Three Financial Risk Control Centers (FRCCs) In 2013, we established an FRCC in London. We chose this city because British people respect rules, especially in the financial sector. We appreciate their conservative approach, not their proactive approach to innovation. We hope to bring a large number of high-end British financial professionals into our company. We expect them to independently assess the financial strategies and architecture that we are working on. We aim to establish rules for everything. Even if something uncertain happens, we have rules to follow. We established an FRCC in Tokyo because Japanese people are meticulous and always dive deep into details. This center helps us better manage our contracts and projects because our end-to-end delivery usually lasts about two to three years. They will check whether something is poorly managed during this period, whether there are embedded contracts, and whether there has been any violation of rules. If yes, they will produce an independent audit report to inform the relevant staff, such as finance staff, project engineers, and project designers, telling them in which areas they need to improve. The FRCC in New York focuses on studying the macro economy. Huawei can't survive in its own world. At this center, we have a team dedicated to researching oil prices. They monitor the trends of exchange rates and foreign exchange reserves in OPEC countries and predict how their exchange rates will change and whether they will impose controls on foreign exchange. We want to figure out how we can improve today from the standpoint of tomorrow. (Meng Wanzhou: Outline of the Report on the Operations of the Financial Risk Control Center in London, 2017)

Three Layers of Review This is a special system. In many companies, CFOs are independent, but Treasury and Accounting may not. At Huawei, we assign a CFO to each business manager. In addition to the CFOs we have deployed in countries and regions, and for customers, we also assign a CFO for each large contract and each project. The Human Resource Management Department and the General Procurement Department also have their own CFOs. What do these CFOs do? First, they offer specialist support, helping business teams to make better-informed decisions. Second, they identify risk items during their independent reporting, and escalate the issues to upper-level management, reminding them to intervene and resolve the issues. (Meng Wanzhou: Outline of the Report on the Operations of the Financial Risk Control Center in London, 2017) 


\subsubsection{Two Perspectives of Financial Risk Control}

Huawei implements its financial risk control system from two perspectives: The first is from an external perspective. The three centers in London, Tokyo, and New York work together to create synergies. The center in London aims to use the certainty of rules to deal with future uncertainty. The center in Tokyo looks at the smallest unit of operations. And the center in New York looks at how we can improve today from the standpoint of tomorrow.

The other perspective is an internal one. In addition to the three centers, we also have three layers of review. The first layer is daily reconciliation. The Treasury Management Department completes bank reconciliation on a daily basis to ensure that every cash flow comes from accounting treatment. The second layer is accounting. This function ensures that processes are followed, authority is properly exercised, and accounting is accurately handled. The third layer is independent CFOs, who establish onsite checks and balances for business decisions. (Meng Wanzhou: Key Points of the Report on Risk Monitoring, 2017)

\subsubsection{Three Financial Risk Control Centers}

Now we need to determine the different focuses of the three FRCCs. British people respect rules and are good at setting rules, so the FRCC in London is responsible for setting rules for each country and each industry. Japanese people are down-to-earth. They are good at doing projects, so the center in Tokyo should focus on project risk management. Americans have a global view, so the center in New York focuses on macroeconomic research. Leveraging the different strengths of the three nations, we can establish three pillars to support our operations. (Ren Zhengfei: Speech at the Meeting with the Finance Management Philosophy Editorial Board, 2017)

The FRCC in London provides guidelines on financial policies, tax policies, and implementation rules for Huawei

Why did Huawei choose to establish an FRCC in London? It's because the UK has mature rules and institutions. The legal, financial, and tax frameworks in the UK are widely applied by other countries. This unique strength enabled the UK to be the first country to move beyond the 2008 financial crisis. And following the crisis, London has further consolidated its position as a global financial center. Specifically, there are three reasons: 
First, timing. Since the seventeenth century, London has been a world economic and trade center. Today the city is home to the world's largest financial derivative market and $49 \%$ of global financial derivative deals take place there.

Second, location. London is an inclusive financial center and can easily cover regions like Europe, Africa, the Middle East, and Central Asia. It is the first city that has launched a prudent oversight plan for the financial sector.

Third, talent. London has more than one million financial professionals, far exceeding Frankfurt and Paris. And the pay of senior financial professionals is lower than in China.

Huawei's FRCC in London is specialized in three key areas: accounting, tax, and treasury. It manages process design, financial strategies, operations quality, and compliance risks from end to end. This center aims to use the certainty of rules to deal with the uncertainty of results and provide guidelines on financial policies, tax policies, and implantation rules for Huawei globally. The center also sets country-specific policies to deal with tax risks. Here is an example of how the FRCC has played its role. Before the crises in Russia and Greece broke out, the center identified the risks and transferred funds out of these countries to secure our assets. The center systematically manages the settlement of transactions worth US\$1.2 trillion and the associated liquidity risks, covering more than 180 countries and regions and over 145 currencies. (Meng Wanzhou: Key Points of the Report on Risk Monitoring, 2017)

The FRCC in Tokyo focuses on project risk control

The FRCC in Tokyo focuses on project management. Japanese people are willing to focus on details. They are good at turning complicated things into simpler ones and doing simple things right the first time. They are meticulous in project baseline and budget management. They even have the courage to halt projects if risks are detected. Their philosophy of project risk management is that exceptions are allowed, but accidents are not.

The meticulousness and craftsmanship of Japanese people - always seeking to do things even better - have enabled the country to establish the highest-standard benchmark in project management around the world. This is why we have established an FRCC in Tokyo, focusing on project operations. Project operations are about examining our management opportunities and making improvements through business case 
design, negotiations, risk estimation, project execution monitoring, and final accounting upon project completion. We can identify areas for systematic improvement from the details of our project operations, which will drive more thorough improvements in these areas. In terms of project operations, we can prepare a guide like the pilot manual and promote it globally. Our ultimate goal is to fuel project operations, increase soil fertility, and harvest more crops. (Meng Wanzhou: Key Points of the Report on Risk Monitoring, 2017)

The FRCC in New York helps the company judge and deal with risks in the macro economy

The US's economic cycle and dollar trends directly affect the global economy, and decisions of the US also directly influence geopolitics and national risks. New York is where the decisions are made. It marks the trail that the rest of the US economy and financial sector will follow. As a financial center, New York has a broad horizon, enabling the city to forecast long-term trends, seize the high ground in policy development, and wield global influence.

We established an FRCC in New York so that we can leverage its vision and global, broad horizon, and absorb the energy of the universe. We hope to cooperate with leading financing institutions and think tanks on Wall Street to obtain first-hand information, helping our company to make better-informed decisions and respond to risks in the macro economy. We also want to help avoid negative impacts on Huawei caused by black swan events, including political uncertainty and uncertainty caused by trade wars like punitive tariffs on a certain industry. We must also watch out for economic uncertainty, such as global economic trends and uncertainty in exchange rates (e.g. when will the USD reach an inflection point?). We need to take a fine-grained approach to all these issues. (Meng Wanzhou: Key Points of the Report on Risk Monitoring, 2017)

\subsection{Financial Risk Prevention and Control}

\subsubsection{We Need to Have Contingency Plans to Deal with Financial Crises, But the Key Is Improving Contract Quality}

First, what was most affected by financial crises? The bubble economy. Companies that had the biggest bubbles, such as those in the financial and real estate sectors, suffered most in financial crises. Second, telecommunication services cost small amounts of money and don't fluctuate 
significantly with the changes in the financial sector. Third, as the digital deluge approaches, demand for network bandwidth will increase. (Ren Zhengfei: Comments at a Meeting with Sales Financing Experts, Huawei Executive Office Speech No. [2012] 025)

We face different risks in different countries, at different times, and under different scenarios. We must have a contingency plan for each specific risk to minimize losses and avoid a conservative approach to our business. (Ren Zhengfei: Remarks at Meetings with the UK RerD Center, Beijing Research Center, and Financial Risk Control Center in London, Huawei Executive Office Speech No. [2015] 075)

Due to an unfavorable global economic environment, credit risks may arise among our key customers, which may result in their inability to make payments on time. For example, in the first half of the year, Brazil's Oi applied for bankruptcy, and India's Reliance faced debt risks. This situation placed clear requirements on us: Huawei's growth must be built on high-quality contracts. If an international political crisis arises, we will survive if we still have money to buy bread. If we don't have money, what should we do? We must not do things randomly. Instead, we must strengthen contract management, and focus on increasing efficiency and profitability in the marketplace. In particular, we must strengthen contract management in countries where there are higher risks related to payment collection. We need to increase the proportion of advance payments, and decrease the proportion of payment upon receipt of the Final Acceptance Certificate (FAC), so as to ensure quality growth this year. (Ren Zhengfei: There Will Not Always Be Flowers Along the Road AheadSpeech at the HI Huawei Market Conference, Huawei Executive Office Speech No. [2016] 079)

We must have contingency plans in place to deal with financial crises, and we must improve our risk control and operational compliance oversight through organizational building and manager deployment. ( $X u$ Zhijun: Focusing on Creating Value for Customers, Achieving Sustainable Growth, Huawei Executive Office Speech No. [2016] 099)

When our revenue reaches US\$200 billion, the FRCC in London alone will not be enough to support our operations. We must develop our FRCCs in Japan and New York to better control financial risks associated with projects and the macro economy. (Source: Minutes of the Work Summary During the Rotating Period [April to September 2015] and Relevant Discussions, BOD Executive Committee Meeting Minutes. No. [2016] 004) 


\subsubsection{Taking Diversified Approaches to Financing and Settlement}

To disperse financial risks, we must become less reliant on loans from Chinese banks, pay more attention to local financing, and build a stronger local financing team. (Source: Minutes of the Report on the 2012 Group Budget Review, EMT Meeting Minutes No. [2012] 012)

We need to take diversified approaches to financing and settlement, and reduce foreign exchange losses by spending local currency locally as much as possible. In Japan and Europe, a good proportion of local settlements are done in local currencies, which partially hedges our foreign exchange position. In these countries and regions, we don't need to convert local currencies into USD. In countries where local currencies have no way to be used, we assume exchange risks. (Ren Zhengfei: Speech at the EMT ST Meeting, March 30, 2012)

The more rapidly we develop, the higher the risks we will encounter. We face great risks in our operations. In the 170-plus countries and regions where we operate, we face all kinds of risks, including war, disease, and currency-related issues. We have set up an FRCC in London. Last year, this center effectively controlled risks concerning the settlement of over CNY5 trillion in 145 currencies from 178 countries, and managed to minimize financial losses to our company. We will also establish FRCCs in Tokyo and New York, where we can leverage excellent global talent to manage and control risks with the company's funds, contracts, and project management. Great achievements have been made in this area, laying a solid foundation for the company to go global. (Ren Zhengfei: Dedicated to China's Century-old Dream of Revitalizing Science and Technology, Huawei Executive Office Speech No. [2016] 067)

\subsubsection{Do Not Stop Progressing Because of Risks or Ignore Risks in Order to Progress}

The company must establish an early warning and rapid response system to predict and sense any subtle but major changes in the external environment caused by competitors, customers, suppliers, and policies and regulations. (Source: The Huawei Charter, 1998)

Risk management involves resolving problems immediately after they occur and taking measures beforehand to foresee and prevent risks. But this does not mean that we need to build huge organizations or processes. 
Instead, we need to gradually improve our risk management framework on the basis of existing processes and management systems. (Source: Minutes of the Work Report on Risk Management, EMT Meeting Minutes No. [2005] 059)

We do not stop progressing because of risks, or ignore risks in order to progress. We have strict rules: Making opportunistic financial investments and using financial leverage are both forbidden. We cannot afford to run risks on two fronts at the same time. (Ren Zhengfei: Remarks at Meetings with the UK REDD Center, Beijing Research Center, and Financial Risk Control Center in London, Huawei Executive Office Speech No. [2015] 075)

\subsection{Business Continuity Management}

\subsubsection{Huawei's Primary Obligation: Maintaining Stable Network Operations}

Our business is to construct networks. Networks with global coverage must be stable at all times. Our products and services are now found everywhere: plateaus where there is a lack of oxygen, scorching hot deserts, the frozen Arctic Ocean, dangerous areas full of land mines, forests, rivers, oceans, and more. Wherever there are people, there are our products and services. (Ren Zhengfei: Speech on Cherishing Life and Assuming Professional Responsibilities, Huawei Executive Office Speech No. [2011] 009)

Our obligation is to maintain stable network operations. This is different from stores that sell tofu and fried dough, because they can be closed whenever their owners like. We can never do this. When there is a disaster or a war, we have to do everything we can to maintain basic network stability. (Ren Zhengfei: Speech on Cherishing Life and Assuming Professional Responsibilities, Huawei Executive Office Speech No. [2011] 009)

Turmoil may occur at any time. Wherever we are and at whatever time, our responsibility is to maintain basic network stability and never get involved in the politics of any country. (Ren Zhengfei: Speech on Cherishing Life and Assuming Professional Responsibilities, Huawei Executive Office Speech No. [2011] 009)

Our managers and administrative departments must develop contingency plans for possible emergencies. While the company is implementing a contingency plan to respond to a crisis, all departments must take their due share of responsibility to ensure that the company's business continues to operate normally. (Ren Zhengfei: Speech on Cherishing Life and 
Assuming Professional Responsibilities, Huawei Executive Office Speech No. [2011] 009)

Business continuity is a guarantee of our customer services and our survival, so we must not leave it to luck. To ensure supply security and business continuity, we must boldly make strategic investments, embrace open innovation, draw on the achievements and strengths of others, and make strategic breakthroughs in key technologies, basic software platforms, key chips, and key components. (Source: Overtaking the United States and Enjoying the Ride-Speech by Xu Zhijun at Huawei Annual Management Conference 2013, Huawei Executive Office Speech No. [2013] 244)

\subsubsection{Building Strategic Reserves to Prevent Supply Risks}

In the current economic environment, some of our suppliers may face business problems and may be unable to supply the raw materials we need. To prevent such risks, we can consider taking part of the savings from raw material price cuts as reserve funds to fight against risks. We can use the money to buy extra materials, which can serve as reserve inventory to ensure our normal production and supply security. We can also use this money to reward outstanding suppliers and those who have demonstrated outstanding performance, which will in turn bring Huawei more benefits. (Ren Zhengfei: Speech at the Report on the 2009 Business Strategy by the Procurement Qualification Management Department, EMT Meeting Minutes No. [2009] 013)

We must maintain the right level of inventory to ensure our survival. We allow no risk to this part of inventory. We must take various measures, such as adopting strategic initiatives to ensure availability of key items, sourcing from multiple regions, and building strategic reserves, to ensure the business continuity of our major network products. (Source: EMT Meeting Minutes No. [2012] 004)

We have two goals in making strategic breakthroughs: Internally, we must survive; externally, we must overtake our competitors. If we are unable to achieve these goals, all our efforts will become meaningless. We must not seek to become a weak company that relies on certain big countries; instead, we must be determined to overtake our competitors and become an industry leader. Since we are several years behind those with advanced technology, we must aim to make strategic and technological breakthroughs, have "spare tires" in place, and overtake our competitors. (Ren Zhengfei: Minutes of the Annual Work Report on Business Continuity and Strategic Breakthroughs, EMT Meeting Minutes No. [2013] 005) 
We need to have a red team and a blue team in our product development division. The red team focuses on honing our competitive edge and the blue team focuses on ensuring that we have "spare tires". Members of the two teams can rotate regularly or move between product releases. Product architecture must be flexible and boards must be interchangeable. (Ren Zhengfei: Minutes of the Annual Work Report on Business Continuity and Strategic Breakthroughs, EMT Meeting Minutes No. [2013] 005)

For strategic reserves, we must follow the "first in, first out" principle and ensure that there is no shortage of supply during replenishment of inventory. During emergencies, we can use the reserved materials to support ongoing sales of spare parts and services. (Ren Zhengfei: Minutes of the Annual Work Report on Business Continuity and Strategic Breakthroughs, EMT Meeting Minutes No. [2013] 005)

\subsubsection{Avoiding the Inclusion of Countries and Regions Affected by War, Civil Unrest, or Epidemics into Emergency-Triggered Management Cycles}

Countries and regions affected by war, civil unrest, or epidemics must be managed differently from those where our business operates normally. These hardship countries must be treated fairly and their emergency response assurance, organizational evaluations, performance appraisals, talent management, incentives, and organizational climate need to be revisited systematically. The Hardship Areas and Position Management Department must provide emergency response assurance for these countries and systematically review their management frameworks and rules to avoid including these countries into emergency-triggered management cycles. (Source: Minutes of the Work Report by the Hardship Areas and Position Management Department, BOD Executive Committee Meeting Minutes No. [2014] 012)

We have eight employees in Yemen. The Hardship Areas and Position Management Department must figure out how to create a better living environment for them. For example, we don't need to change the exteriors of their houses, but we can install steel plates on the interiors, replace window glass with laminated glass, and introduce mechanical ventilation systems. You can go and talk to the Capital Construction Management Department about this. The windows and steel plates for the Yemen office can be bought in China and delivered by air. HQ can bear the expense. The Yemen office only needs to pay installation costs. A report on what was done in Afghanistan can also be published for people to read. None of 
our staff there have been injured despite the ongoing war. In these countries, we need to build a caring environment where everyone feels safe and united. There is nothing more important than the lives of our employees. We must do everything we can to keep them safe and avoid doing anything too risky. When we risk our lives to provide products or services in the face of war or violence, then the price of our products should go up. We're not trying to extort anyone, but we need to let carriers understand our situation. That way, we can break even in small countries. Turning in profits to the company is not important here. (Ren Zhengfei: Minutes of the Briefing on the Progress of Differentiated Appraisals for Regions, Huawei Executive Office Speech No. [2015] 050)

During administrative services management, we must look at more than just the size of a country. We must also consider how tough it is to work and live in that country. We need to make all this very clear, because it is not easy to provide a comfortable environment in hardship regions. (Ren Zhengfei: Improving the Working Environments in Hardship Countries-Speech at the EMT ST Meeting on March 7, 2016, Huawei Executive Office Speech No. [2016] 037)

\subsection{Using the Certainty of Legal Compliance TO DEAL WITH THE UNCERTAINTY OF INTERNATIONAL Politics}

\subsubsection{Legal Compliance Is the Most Important Basis on Which We Survive, Provide Services, and Contribute Worldwide}

Individual income tax risks are mainly faced overseas. The purpose of complying with applicable laws in countries outside China is to ensure our operational security there. In China, our principle in complying with individual income tax laws is to be a follower; innovation is not encouraged. (Ren Zhengfei: Minutes of the Meeting on Individual Income Tax Related Problems, 2011)

All employees must respect and strictly observe laws and regulations. No one should think they are above the law. (Source: Employees Must Comply with Laws, EMT Resolution No. [2015] 016)

Huawei is obliged to comply with all applicable laws and regulations, including Chinese laws about managing the information on content operations platforms. (Source: Employees Must Comply with Laws, EMT Resolution No. [2015] 016) 
The primary goal of the Legal Affairs Department is not to put out fires or win lawsuits, but to prevent fires. (Ren Zhengfei: Speech at a Meeting with Employees of the Legal Affairs Department, Secretariat Office of the Board of Directors, and Wireless Network Product Line, Huawei Executive Office Speech No. [2015] 015)

Guo Ping has said that we must use the certainty of legal compliance to tackle the uncertainty of international politics. He has shown us where we should be heading as we deal with international relations. (Ren Zhengfei: Be First to Know When Springtime Comes. Vow Not to Return Till We Reach Our Goals-Speech at an Oath-taking Rally for Reassigned Senior RED Experts and Managers, Huawei Executive Office Speech No. [2016] 093)

As we face an increasingly complicated business environment, we must leverage the certainty of legal compliance to tackle the uncertainty of international politics, to bridge discontinuity in the macro environment. (Xu Zhijun: Focusing on Creating Value for Customers, Achieving Sustainable Growth, Huawei Executive Office Speech No. [2016] 099)

As long as China continues with its reform towards the rule of law and the market economy, it will be a more powerful country and will make greater contributions to the world in the coming decades. Huawei has a business presence in over 170 countries and regions. Legal compliance is the most important basis on which we survive, provide services, and contribute worldwide. We abide by laws of the countries and regions where we operate, and by United Nations resolutions. In sensitive regions, we regard the laws of the US as international laws. If we didn't do so, it would be impossible for us to go global. (Ren Zhengfei: Dedicated to China's Century-old Dream of Revitalizing Science and Technology, Huawei Executive Office Speech No. [2016] 067)

The world today is full of uncertainty and crises. We must strictly abide by rules and laws, and use the certainty of legal compliance to tackle the uncertainty of international politics. We must strictly monitor internal and external compliance, and operate within the boundaries of our business. (Ren Zhengfei: Dedicated to China's Century-old Dream of Revitalizing Science and Technology, Huawei Executive Office Speech No. [2016] 067)

Over the next three to five years, our company may face huge risks, so we must abide by the law and use the certainty of legal compliance to tackle the uncertainty of international politics. The world is undergoing tremendous changes. The only thing we can do is to ensure legal compliance in the countries and regions where we operate. (Ren Zhengfei: There 
Will Not Always Be Flowers Along the Road Abead-Speech at the 2016 HI Huawei Market Conference, Huawei Executive Office Speech No. [2016] 079)

First, Huawei is a company. We must not engage in politics, as that is the job of politicians. And we are not familiar with politics. We must serve our customers in a down-to-earth manner. That is how we can achieve success. (Ren Zhengfei: Minutes of a Meeting with Employees of the Japan Representative Office and the Japan Research Center, Huawei Executive Office Speech No. [2016] 080)

\subsubsection{Focusing on Protecting User Privacy in the Same Way We Have Done in Cyber Security}

The public, governments, and customers are increasingly concerned about user privacy protection. Therefore, to develop our consumer and enterprise businesses, we need to enhance user privacy protection. Just as what we have done in cyber security, we will make important commitments to the public, governments, and customers on user privacy protection to fulfill our corporate responsibilities. We will take all possible measures to enhance user privacy protection. (Source: Resolution on Enhancing User Privacy Protection, EMT Resolution No. [2014] 031)

Business managers take full responsibility for cyber security and user privacy protection within their own business domains. Process owners take full responsibility for cyber security and user privacy protection within their respective processes. Managers in BGs and BUs are responsible for all operating results, including technological competitiveness, market share, profit and loss, as well as for cyber security and user privacy protection. (Source: Resolution on Enbancing User Privacy Protection, EMT Resolution No. [2014] 031)

\subsection{Compliance Management and Subsidiary BoArds' Oversight Responsibilities}

\subsubsection{Strengthening Compliance Management to Harvest More Crops}

We must ensure the operational compliance of overseas representative offices, subsidiaries, and research institutes to avoid negative incidents. (Source: 2010 Key Work Requirements, EMT Resolution No. [2010] 007) 
Any non-compliance may have major impact or even cause fatal damage to our company's reputation and our continued, stable development around the world. (Ren Zhengfei: Promoting Operational Compliance of Subsidiaries to Support the Company's Robust Growth, Huawei Executive Office Speech No. [2015] 012)

Principles for managing compliance risks:

1. We must set a clear goal and plan for compliance management. We then need to classify countries into different categories based on the stringency of their compliance requirements, their population, and our in-country business volume. We need to set and implement a compliance plan for the next three years to ensure that our core business complies with all applicable laws before the end of that period.

Compliance risks are dynamic and relative, not absolute. If the company does not give a risk a green light, we must ensure compliance unconditionally. For high-level risks that may have severe impacts on the company's major business, reputation, and brand image, we must set red lines and ensure that these basic requirements are met first.

2. For all compliance risks, we must achieve pre-set compliance goals within the required timeframes. For individual risks for which we cannot ensure $100 \%$ compliance for the moment, we must monitor them in real time, manage the progress of improvement, and monitor the status of the risks. (Source: Minutes of the Report on the Work Priority "Building and Improving the Overseas Operational Compliance Management Mechanism, Regulating Subsidiary Management Operations, and Establishing Oversight-oriented Boards at All Overseas Subsidiaries", BOD Executive Committee Meeting Minutes No. [2014] 017)

Don't be afraid during the compliance management process. We must move forward cautiously and ensure we do not cross any red lines. In the future, we will accept fines if they come as a result of crossing a red line due to a lack of capabilities despite a collective decision. What we will not accept is paying the price for ignorance. (Ren Zhengfei: Remarks During Visits to Countries Where Cash Is Trapped, Huawei Executive Office Speech No. [2015] 023) 
Subsidiary boards oversee compliance to make sure we comply with laws and regulations while harvesting more crops. This is also our longterm goal. Any short-term dip in revenue must be in the service of that long-term goal. Compliance isn't an excuse for harvesting less crops. That is an outdated, false understanding of what compliance means. (Ren Zhengfei: Speech at the Mid-year Workshop on the Enablement of Subsidiary Board Directors, Huawei Executive Office Speech No. [2014] 074)

We must enhance compliance management and improve our related capabilities. In the future, we will boost our capability to manage compliance by training managers or through lectures and self-learning sessions, much like those given in Egypt. (Ren Zhengfei: Remarks During Visits to Countries Where Cash Is Trapped, Huawei Executive Office Speech No. [2015] 023)

The goals of our oversight-oriented subsidiary boards are the same as those of our operating teams, which are to harvest more crops and increase soil fertility. Here crops not only include sales revenue, but also profits and cash flow. By harvesting more crops, we aim for profitable revenue and healthy cash flow. Currently, our oversight-oriented subsidiary boards are responsible for overseeing subsidiaries' internal and external compliance, managers, accounting compliance, and operating results. In the future, they may also act as a platform for public relations, legal affairs, and logistics support. The boards and operating teams will each play their own roles, and operating teams can move forward nimbly while complying with relevant laws and rules. (Ren Zhengfei: Speech at the Meeting on Extension of the Company's Oversight and Management Control System, Huawei Executive Office Speech No. [2017] 041)

\subsubsection{Subsidiary Boards: Performing Integrated Oversight in the Field on Behalf of the Company Without Interfering in Business Operations}

We must delegate more authority to field offices, allowing those who are closest to customers to make business decisions. At the same time, we must strengthen oversight and management. (Ren Zhengfei: Success Is Not a Reliable Guide to Future Development-Speech at the Huawei Market Conference on January 17, 2011, Huawei Executive Office Speech No. [2011] 004)

Our policies are clear: We must establish only one platform and have only one controlling entity in every country. We must not register multiple companies in one city. This can help improve our governance 
structure, regulate the establishment of legal entities in countries, and ensure operational and legal compliance. (Ren Zhengfei: Speech at a Workshop on Europe's Business Environment, Huawei Executive Office Speech No. [2013] 054)

Let's allow people who can hear the gunfire to call for artillery. It's important that we promptly delegate decision-making authority to the field and at the same time prevent the field from acting randomly. As such, our oversight system must also be moved to the field by leveraging the power of the company's capital. Capital management is not a part of our normal processes. As our forces quickly advance, it's the job of subsidiary board directors to sit and observe. If they spot a problem, they need to take a helicopter to get to the heart of the problem. This is not a processbased action. On behalf of the company, our subsidiary boards leverage the power of capital to provide oversight. International laws support such capital management. But remember not to interfere in business operations. (Ren Zhengfei: Speech at the Mid-year Workshop on the Enablement of Subsidiary Board Directors, 2014)

Why should subsidiary boards become an integrated governance platform? In the future, our revenue will be far more than 70 billion US dollars and may reach 100 or even 200 billion US dollars. We are not sure how large data traffic will become. We must have an integrated management platform in place. Only in this way can we promptly satisfy customer needs and delegate authority to operating teams. If we don't do this, it will be impossible for us to scale out. We now have one platform. In the future, we will have an integrated management platform consisting of more than 100 subsidiary boards, enabling us to promptly respond to and satisfy customer needs. Over the past two years, we have followed the needle-tip strategy and have become very likely to be the industry leader in terms of technology. Our talent pyramid was stable in the past, but to inspire passion across the company, we need to further optimize the pyramid. Within three to five years, we will implement all our management transformations and reach the same management standards as Western companies. In five to ten years, we will delegate business decision-making authority to teams that are closest to customers. After that, the integrated platform will play an important role. We must pay attention to this. We also need to strengthen financial management and integrated management. We need to readily recognize staffing of the finance division. (Ren Zhengfei: Speech at the Briefing on the Deployment of Subsidiary Boards of Directors Outside China, Huawei Executive Office Speech No. [2014] 048) 
Subsidiary boards are currently focusing on compliance oversight, and have identified a number of pressing problems relating to labor, taxation, and permanent establishment. These problems are the same ones we have seen in field offices. Most managers focus more on business management and strategic operations, and pay less attention to these problems. We're currently stepping up efforts to develop our enterprise and consumer businesses, so our problems are now more exposed to public scrutiny than in the past. By establishing subsidiary boards at this time and by using oversight to bridge the gaps I mentioned, our operations will be more robust, which will be conducive to our future growth. (Ren Zhengfei: Speech at the Mid-year Workshop on the Enablement of Subsidiary Board Directors, Huawei Executive Office Speech No. [2014] 074)

We must enhance our legal entity management capabilities in overseas subsidiaries.

1. The Investments Management Department has launched a series of projects to build legal entity management capabilities in overseas subsidiaries. They have developed subsidiary entity management processes, improved the processes of determining specific functions undertaken by subsidiaries, refined subsidiary management policies, and improved subsidiary compliance capabilities. Relevant policies and plans need to be completed by the end of 2014 and implemented in 2015.

2. In the legal entity management of overseas subsidiaries, we must focus on major subsidiaries, especially entities responsible for a wide range of functions, such as the subsidiaries in the UK, France, Germany, and Malaysia. We need to optimize their governance structure and pilot appointing subsidiary general managers to manage all entities at the subsidiary level. We must effectively manage subsidiary legal entities and build a platform to support business development and resource allocation.

3 . We must focus on countries where compliance risks are high, especially the US. Have we bought insurance for subsidiary board directors? We must enhance our risk prevention measures for individual directors. (Source: Minutes of the Report on the Work Priority "Building and Improving the Overseas Operational Compliance Management Mechanism, Regulating Subsidiary Management Operations, and Establishing Oversight-oriented Boards at All Overseas Subsidiaries", BOD Executive Committee Meeting Minutes No. [2014] 017) 
Over the next five years, our annual revenue will top US\$100 billion. We will definitely delegate authority to the very front line. That means we will no longer have one, centralized management platform, but several decentralized ones. So we will need a neutral organization to oversee our field operations on behalf of the company. That will be the mission of our subsidiary boards. (Ren Zhengfei: Speech at a Briefing on the Solution for Management Oversight by Oversight-oriented Subsidiary Boards and the Pilot Results, Huawei Executive Office Speech No. [2015] 072)

Subsidiary boards are authorized to exercise onsite oversight on subsidiary operations on behalf of the company and are organizations with their own inherent authority. Auditing, inspection, internal controls, offices of ethics and compliance (OECs), legal affairs, and other departments are organizations responsible for execution. They need to support subsidiary boards in exercising their oversight authority. Subsidiary boards must show the value of authority and must not try to grab or take over the work of these supporting departments. These departments will ultimately report to the subsidiary boards. (Ren Zhengfei: Speech at a Briefing on the Solution for Management Oversight by Oversight-oriented Subsidiary Boards and the Pilot Results, Huawei Executive Office Speech No. [2015] 072)

Today, the Legal Affairs Department manages compliance on behalf of the company and implements rules and systems, including programs. This is a highly centralized approach where the Legal Affairs Department reports directly to the corporate Board of Directors. In the future, we will change this centralized governance approach by delegating authority to the field, with the local legal and oversight functions in place reporting to subsidiary boards and higher-level business departments. Without this change, HQ will become bloated. In the future, we will gradually delegate more authority to field offices because they know the most about the business and are closest to customers. Despite this, people who are delegated authority must be subject to oversight, so our oversight teams must also be moved forward into the field. That does not mean that HQ will no longer play any oversight role. Instead, HQ will become more specialized, and will use its expertise to support oversight in field operations. Local legal affairs teams will report compliance statuses to subsidiary boards, local business management teams, and the President of the Legal Affairs Department at HQ. Local legal affairs teams also play their part in building compliance capabilities. (Ren Zhengfei: Speech at a Meeting with the Managerial Control Elite Team, Huawei Executive Office Speech No. [2015] 060) 
The company's Supervisory Board will assist the Subsidiary Board Directors Resources Bureau and the Investments Management Department in setting up subsidiary boards, which in turn will be managed directly by the Supervisory Board in the future. The Subsidiary Board Directors Resources Bureau and the Investments Management Department must focus on training subsidiary board directors and increasing the number of full-time directors at the Subsidiary Board Directors Resources Bureau. Any manager reassigned to another position must receive training in the Managerial Control Elite Team before being appointed to another managerial position, or they may spend some time as a director on a subsidiary board. There must be a two-way flow between the two. (Ren Zhengfei: Speech at a Briefing on the Solution for Management Oversight by Oversightoriented Subsidiary Boards and the Pilot Results, Huawei Executive Office Speech No. [2015] 072)

Subsidiary boards are responsible for operational compliance as we go global. Because each board member was previously a trusted senior staff member who held a managerial position at Huawei for many years, we can consider granting them the authority to approve operational matters (but not approving decisions) in the IT system. In this way, the Chinese members of subsidiary boards can be authorized at the operational level under a given framework so that both business decision-making and oversight authority can be moved to the field. This can also place constraints upon solution design departments. (Ren Zhengfei: Remarks During Visits to Countries Where Cash Is Trapped, Huawei Executive Office Speech No. [2015] 023)

Our subsidiary boards oversee subsidiary operations on behalf of the company. They must be good at identifying and exposing problems. Their role is not to interfere in field operations or to help field offices cover up problems. Subsidiary boards may sometimes take steps to smooth ruffled feathers, but that is not their goal. Their ultimate goal is still to help win hard battles and to harvest more crops. (Ren Zhengfei: Speech at a Briefing on the Solution for Management Oversight by Oversight-oriented Subsidiary Boards and the Pilot Results, Huawei Executive Office Speech No. [2015] 072)

Rather than be merely limited to external compliance, subsidiary boards need to extend their responsibilities to also include internal compliance. Both areas are vital, and subsidiary boards must fulfill their oversight responsibilities by paying attention to both risks and risk control mechanisms. 
First, risks. The first thing is to scan for high-risk areas. Subsidiary boards can obtain information from sources including (a) audit, internal control, HR, and legal affairs departments; (b) past cases of incompliance in the region, indicating which issues have recurred multiple times; and (c) by identifying high-risk areas and analyzing high-risk scenarios within these areas.

Second, systems. Look at the risks and management blind spots that you've discovered, and check whether the subsidiary management team is effectively implementing Huawei's policies. Have they put in place effective processes and oversight measures? Have they effectively organized employee education, management, investigation, disciplinary, and legal efforts? Are there significant gaps in their systems? Subsidiary boards must remind the management team to make improvements as needed. (Ren Zhengfei: Speech at a Briefing on the Solution for Management Oversight by Oversight-oriented Subsidiary Boards and the Pilot Results, Huawei Executive Office Speech No. [2015] 072)

We have established multiple subsidiary boards staffed by former regional presidents and former senior representative office general managers. These subsidiary boards are in charge of internal and external compliance, and are accountable for overseeing operations in subsidiaries. Members of these subsidiary boards are independent. They don't have to have group discussion. Group discussion is only necessary when there is a major issue. Without group discussion, board members can look into any issue that may lead to a major crisis. This shows their loyalty. The company will not intervene in their commendations, promotions, or rewards. However, their removal from positions or criticism directed against them must be approved by the company's top management. This mechanism is able to properly constrain a huge sales team that is made up of inexperienced young people, and develop them into an effective team that is wellorganized, well-disciplined, courageous, and dedicated. (Ren Zhengfei: Dedicated to China's Century-old Dream of Revitalizing Science and Technology, Huawei Executive Office Speech No. [2016] 067)

Our subsidiary board members must have the courage to expose problems and effectively manage the boundary between internal and external compliance. They must not break rules, or give or accept bribes. We don't want to see corruption at Huawei. And we don't want to see our employees break the laws of the countries where they work or even the laws of the United Nations. We must not break US laws, either. Everything we do 
must be within the bounds of law. We are just businesspeople and our job is to do business. (Ren Zhengfei: There Will Not Always Be Flowers Along the Road Abead-Speech at the HI Huawei Market Conference, Huawei Executive Office Speech No. [2016] 079)

Compliance-oriented subsidiary boards will continue to serve as a rubber stamp. Our current focus is to establish oversight-oriented subsidiary boards. When we make some progress, we can combine compliance- and oversight-oriented subsidiary boards, and create a true authority. If they are only compliance-oriented, they will need to dive into too many details, which may make it difficult for them to focus. (Ren Zhengfei: Speech at the Meeting on Extension of the Company's Oversight and Management Control System, Huawei Executive Office Speech No. [2017] 041)

Open Access This chapter is licensed under the terms of the Creative Commons Attribution-NonCommercial-NoDerivatives 4.0 International License (http:// creativecommons.org/licenses/by-nc-nd/4.0/), which permits any noncommercial use, sharing, distribution and reproduction in any medium or format, as long as you give appropriate credit to the original author(s) and the source, provide a link to the Creative Commons licence and indicate if you modified the licensed material. You do not have permission under this license to share adapted material derived from this chapter or parts of it.

The images or other third party material in this chapter are included in the chapter's Creative Commons licence, unless indicated otherwise in a credit line to the material. If material is not included in the chapter's Creative Commons licence and your intended use is not permitted by statutory regulation or exceeds the permitted use, you will need to obtain permission directly from the copyright holder. 